\title{
Review
}

\section{Male reproductive organs are at risk from environmental hazards}

Jens Peter Bonde

Department of Occupational and Environmental Medicine, Bispebjerg University Hospital, DK-2400 Copenhagen NV, Denmark

\begin{abstract}
Male reproductive disorders that are of interest from an environmental point of view include sexual dysfunction, infertility, cryptorchidism, hypospadias and testicular cancer. Several reports suggest declining sperm counts and increase of these reproductive disorders in some areas during some time periods past 50 years. Except for testicular cancer this evidence is circumstantial and needs cautious interpretation. However, the male germ line is one of the most sensitive tissues to the damaging effects of ionizing radiation, radiant heat and a number of known toxicants. So far occupational hazards are the best documented risk factors for impaired male reproductive function and include physical exposures (radiant heat, ionizing radiation, high frequency electromagnetic radiation), chemical exposures (some solvents as carbon disulfide and ethylene glycol ethers, some pesticides as dibromochloropropane, ethylendibromide and DDT/DDE, some heavy metals as inorganic lead and mercury) and work processes such as metal welding. Improved working conditions in affluent countries have dramatically decreased known hazardous workplace exposures, but millions of workers in less affluent countries are at risk from reproductive toxicants. New data show that environmental low-level exposure to biopersistent pollutants in the diet may pose a risk to people in all parts of the world. For other toxicants the evidence is only suggestive and further evaluation is needed before conclusions can be drawn. Whether compounds as phthalates, bisphenol A and boron that are present in a large number of industrial and consumer products entails a risk remains to be established. The same applies to psychosocial stressors and use of mobile phones. Finally, there are data indicating a particular vulnerability of the fetal testis to toxicants - for instance maternal tobacco smoking. Time has come where male reproductive toxicity should be addressed form entirely new angles including exposures very early in life.
\end{abstract}

Asian Journal of Andrology (2010) 12: 152-156. doi: 10.1038/aja.2009.83; published online 7 December 2009.

Keywords: epidemiology, fertility, occupation, risk factors, semen quality

\section{Introduction}

There are several reasons why reproductive and environmental epidemiologists have taken interest in male reproductive health. Infertility is a common

Correspondence to: Prof. Jens Peter Bonde, Department of Occupational and Environmental Medicine, Bispebjerg University Hospital, Bispebjerg Bakke 23, Building 33, DK-2400 Copenhagen NV, Denmark.

Fax: +45-3531-6070

Received: 23 October 2009

E-mail: jpb@bbh.regionh.dk

Accepted: 5 November 2009

Published online: 7 December 2009 disorder affecting some $10 \%-15 \%$ of all couples trying to conceive and subfertility has become a dramatically increasing problem in affluent countries. Couples postpone having children to after 30 years of age, where the biological fecundity of women rapidly starts to decline. Although it still is a matter of conjecture whether human sperm counts have declined during some time periods [1], it has during past 10-20 years become established that young men in some regions have semen quality that is suboptimal with a reference to sperm count values that provide the greatest probability to fertilize [2]. In Denmark and other countries some $25 \%-40 \%$ of young men have 
sperm counts that are low according to this biological reference [3]. A large and comprehensive population based study in the Chongqing region of Southwest China indicated that $60 \%$ of men had at least one semen characteristic below current World Health Organization (WHO) reference values [4]. The causes of low sperm count and poor semen quality are unknown in the vast majority of cases. From a toxicological point of view the spermatogenesis is expected to be vulnerable to reproductive toxicants because of the continuously ongoing large number of cell divisions and sperm cell diffentiation and maturation processes. Indeed, a large number of toxicological studies in rodents documents that specific cells and specific stages of sperm cell development are vulnerable to specific toxicants (Figure 1). Moreover, sad experience from the occupational arena clearly documents that also human spermatogenesis may be vulnerable to chemicals at very low exposure levels not causing intoxication. The dibromochloropropane (DBCP) tragedy that was disclosed in 1977 in California [5] and the subsequent year in Israel [6] was a strong impetus for intensified research into environmental hazards to male reproductive health [7] (Figure 2).

\section{Occupational hazards}

Boron is a light metal that has wide-spread industrial uses. Testicular toxicity has been demonstrated in rat, mice and dogs at rather low dose levels in the range of 17-20 mg boron per kg body weight per day [8]. Since testicular toxicity in rodents is a good predictor of testicular toxicity in humans, the experimental results are of major concern. Most highly exposed are workers implied in boron mining and processing. There are indications that exposure to boron is related to change of the ratio between $\mathrm{X}$ and $\mathrm{Y}$ bearing spermatozoa in human ejaculate [9], but so far there are no indications that boron exposure cause reduced sperm counts in the boron mining industry [10]. It is well-established that radiant heat can reduce sperm counts with a delay of some weeks and occupational studies have indeed shown that foundry and steel workers, specialized welders, and bakers may have reduced fertility and sperm counts [11, 12].

Since several studies have shown that the sitting position in office work is associated with higher scrotal temperature than work in the standing or walking position, the posture might be an important factor in

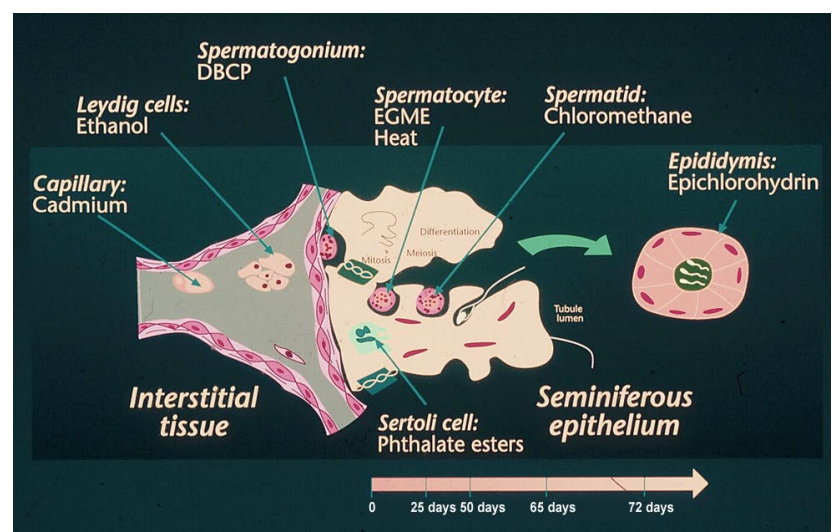

Figure 1. Experimental evidence on male reproductive toxicity of chemicals targeting specific cells of male reproductive tissues.

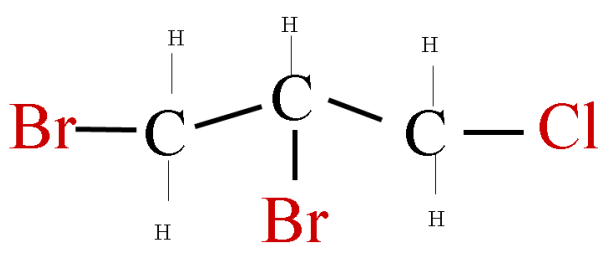

Figure 2. The molecular structural formula of dibromochloropropane $(\mathrm{DBCP})$.

causing reduced fertility in modern societies. However, so far there are no indications that office workers experience impaired fertility because of posture. Although the sitting position may cause increase of scrotal temperature, this increase seems not strong enough to disrupt spermatogenesis that may recover during other parts of the day [13,14]. Research during past 25 years has identified a large number of chemicals and occupational exposures that may impair male fertility (Table 1) [15-26]. It should, however, be acknowledged that epidemiological studies of male fertility and semen quality are beset with a number of pitfalls and methodological limitations crude exposure assessment, low participation rates, inadequate study size and lacking quality assurance of the semen analysis $[27,28]$. As a result in many cases the evidence must be considered as limited or circumstantial. Notable exceptions are exposure to inorganic lead that reduce sperm counts at exposure levels above $40 \mu \mathrm{g} \mathrm{dL}^{-1}$ blood [41] and possibly impairs fertility at considerably lower levels [42]. Other examples of established risk factors are ionizing radiation, certain organic solvents and certain pesticides. Therefore the general practitioner and the andrologist must bear in mind that occupational 
Table 1. Chemical and physical exposures that have been associated with reduced semen quality or impaired male fertility (for systematic reviews, see [15-26]).

Chemicals and occupational exposures

DBCP among chemical and agricultural workers

Ethylene dibromide among fumigators

Glycol ethers among shipyard painters and others

Metals among stainless and mild steel welders

Lead among lead smelters and car battery manufacturers

Mixture of several pesticides in greenhouse workers

Carbaryl among chemical workers

Perclorethylene among metal workers and drycleaners

Carbon disulfide among workers in viscose rayon production

Styrene among reinforced plastic workers

DDT/DDE in men living and working in endemic malaria areas

Radiant heat in foundry workers

Ionizing radiation

PCB in the general population

Maternal tobacco smoking

Reference(s) No.

[5-7]

[29]

Abbreviations: DBCP, dibromochloropropane; DDT, dichlorodiphenyl-trichloroethane; DDE, dichloro-diphenyl-ethylene; PCB, Polychlorinated biphenyls.

exposure can be a significant factor in unexplained male fertility. If in doubt the patient should be referred for a qualified exposure assessment at an occupational clinic. If a hazardous exposure cannot be eliminated, it may become necessary to transfer the man to other working tasks under close monitoring of semen quality which after months to years may recover following a toxic exposure.

During the past decade environmental exposures have also received attention. Several studies from the Limpopo Province in South Africa and studies from Mexico have consistently indicated impaired semen quality associated with environmental dichlorodiphenyl-ethylene (DDT)-exposure among people living in endemic malarias areas [43, 44]. The question whether malarial fever could explain the results has unfortunately not been addressed. The environmental exposure levels in these studies are high compared to current levels of DDT and DDT-metabolites in populations of other parts of the world, where low-level DDT exposure has not been associated with reduced sperm counts or male infertility $[45,46]$. In any case it is, disturbing that low-level exposure to PCBcongeners apparently interferes with sperm cell motility and sperm chromatin integrity in humans - findings that are consistent with experimental studies [47].

\section{Fetal exposure}

The discovery that testicular cancer originates in fetal life has highlighted the possible importance of environmental or industrial exposures taking place early in life and has resulted in the hypothesis that reduced semen quality, testicular cancer and male congenital malformations as hypospadias and cryptorchidism to some degree may share etiologic factors [48]. The fact that fetal exposure may indeed be important is demonstrated by several Danish studies that now consistently indicate that mothers' tobacco smoking during pregnancy is related to rather strong reduction in sperm counts in male offspring. It also seems that fetal exposure to tobacco smoking has stronger impact on semen quality than smoking during adult age [49-53]. Studies of twins, half and full siblings also indicate that early exposures taking place in-utero are important in causing cryptorchidism [54]. When several of the very large mother child cohorts that were established during the 1990 s become old enough to study infertility in the offspring, we can expect to learn much more about the importance of fetal exposures with respect to male reproductive health.

\section{Male mediated development toxicity}

The question whether exposure of men may result in pregnancy failure or disorders in the offspring independent of maternal exposures and conditions is continuously of concern although still unsettled in humans [55]. This question is important, because men may experience more heavy exposure than women and because little attention is paid to this possibility, so men often take no special precautions to avoid harmful exposures during fertile age. In 1995 the US Institute of Medicine Committee stated that "the prevailing view is that exposure of the human male to chemicals and ionizing radiation is generally unrelated to the occurrence of developmental endpoints such as miscarriage, birth defects, growth retardation and 
cancer" [56]. The question is, however, whether lack of convincing examples of male mediated developmental toxicity in humans is due to the non- existence of this phenomenon due to huge methodological challenges in demonstrating effects. A large body of evidence in rodents unequivocally shows that paternal exposure to a variety of chemicals induces embryonic lethality and other abnormal reproductive outcomes [57]. Moreover, chromosomal aberrations in zygotes are critical intermediates between paternal exposure and abnormal reproductive outcomes. There is also strong animal experimental evidence indicating absence of selection against DNA damage (aneuploid) at fertilisation and that male mediated embryonal loss may take place at dose levels not affecting fertility or sperm counts $[58,59]$. Finally, deficient repair mechanisms in the postmeotic sperm cell and the egg cell may be part of the explanation. Nevertheless, it must be acknowledged that we are still awaiting clear evidence for the existence of such a risk in humans. So far, studies of ionising radiation in atomic bomb victims and offspring in relation to paternal smoking have not provided this evidence.

\section{New research avenues}

There has during the past decade been a notable shift in interest from occupational to environmental exposures and from exposures taking place during adult life to exposures taking place in early life - in particular in-utero. It is expected that we during the next decade will learn much more about possible consequences of in-utero exposures to xenobiotics disrupting endocrine regulation, to mutagens and other toxicants, following exposure to nano-particles and possibly consequences of long-term severe psychosocial exposures. Other areas of high interest are gene-environment interaction and male-mediated development toxicity.

\section{References}

1 Giwercman A, Bonde JP. Declining male fertility and environmental factors. Endocrinol Metab Clin North Am 1998; 27: 807-30, viii.

2 Bonde JP, Ernst E, Jensen TK, Hjollund NH, Kolstad $\mathrm{H}$, et al. Relation between semen quality and fertility: a population-based study of 430 first-pregnancy planners. Lancet 1998; 352: 1172-7.

3 Andersen AG, Jensen TK, Carlsen E, Jørgensen N, Andersson AM, et al. High frequency of sub-optimal semen quality in an unselected population of young men. Hum Reprod 2000; 15: 366-72.
4 Li Y, Lin H, Ma M, Li L, Cai M, et al. Semen quality of 1346 healthy men, results from the Chongqing area of southwest China. Hum Reprod 2009; 24: 459-69.

5 Whorton MD, Krauss RM, Marshall S, Milby TH. Infertility in male pesticide workers. The Lancet 1977; 2: 1259-61.

6 Potashnik G, Ben-Aderet N, Israeli R, Yanai-Inbar I, Sober I. Suppressive effect of 1,2.dibromo-3-chloropropane on human spermatogenesis. Fertil Steril 1978; 30: 444-7.

7 Torkelson TR, Sadek SE, Rowe VK, Anderson HH, Loquvam GS, et al. Toxicologic investigations of 1,2-dibromo-3chloropropane. Toxicol Appl Pharmacol 1961: 545-59.

8 Boron. Geneva: World Health Organisation 1998.

9 Robbins WA, Wei F, Elashoff DA, Wu G, Xun L, Jia L, et al. $\mathrm{Y}: \mathrm{X}$ sperm ratio in boron-exposed men. J Androl 2008; 29: 115-21.

10 Liu P, Hu W, Wu GP, Wei FS. [Influence of professional boron exposure on quality of male sperms]. Zhonghua Lao Dong Wei Sheng Zhi Ye Bing Za Zhi 2006; 24: 167-9.

11 Mieusset R, Bujan L. Testicular heating and its possible contributions to male infertility: a review. Int J Androl 1995; 18: $169-84$

12 Thonneau P, Bujan L, Multigner L, Mieusset R. Occupational heat exposure and male fertility: a review. Hum Reprod 1998; 13: 2122-5.

13 Stoy J, Hjollund NH, Mortensen JT, Burr H, Bonde JP. Semen quality and sedentary work position. Int $\mathrm{J}$ Androl 2004; 27: 5-11.

14 Hjollund NH, Storgaard L, Ernst E, Bonde JP, Olsen J. The relation between daily activities and scrotal temperature. Reprod Toxicol 2002; 16: 209-14.

15 Lahdetie J. Occupation- and exposure-related studies on human sperm. J Occup Environ Med 1995; 37: 922-30.

16 Kumar S. Occupational exposure associated with reproductive dysfunction. J Occup Health 2004; 46: 1-19.

17 Jensen TK, Bonde JP, Joffe M. The influence of occupational exposure on male reproductive function. Occup Med (Lond) 2006; 56: 544-53.

18 Bonde JP. Occupational risk to male reproduction. G Ital Med Lav Ergon 2002; 24: 112-7.

19 Henderson J, Baker HW, Hanna PJ. Occupation-related male infertility: a review. Clin Reprod Fertil 1986; 4: 87-106.

20 Perry MJ. Effects of environmental and occupational pesticide exposure on human sperm: a systematic review. Hum Reprod Update 2008; 14: 233-42.

21 Sheiner EK, Sheiner E, Hammel RD, Potashnik G, Carel R. Effect of occupational exposures on male fertility: literature review. Ind Health 2003; 41: 55-62.

22 Figa-Talamanca I, Traina ME, Urbani E. Occupational exposures to metals, solvents and pesticides: recent evidence on male reproductive effects and biological markers. Occup Med (Lond) 2001; 51: 174-88.

23 Baranski B. Effects of the workplace on fertility and related reproductive outcomes. Environ Health Perspect 1993; 101 (Suppl 2): 81-90.

24 Oliva A, Spira A, Multigner L. Contribution of environmental factors to the risk of male infertility. Hum Reprod 2001; 16: 1768-76.

25 Bonde JP. Occupational risk to male reproduction. Int Arch 
Occup Environ Health 1999; 72: 133-4.

26 Jensen TK, Bonde JP, Joffe M. The influence of occupational exposure on male reproductive function. Occup Med (Lond) 2006; 56: 544-53.

27 Bonde JP, Giwercman A, Ernst E. Identifying environmental risk to male reproductive function by occupational sperm studies: logistics and design options. Occup Environ Med 1996; 53: 511-9.

28 Bonde JP, Joffe M, Sallmen M, Petter K, Olsen Jørn O, et al. Validity issues relating to time-to-pregnancy studies of fertility. Epidemiology 2006; 17: 347-9.

29 Ratcliffe JM, Schrader SM, Steenland K, Clapp DE, Turner $\mathrm{T}$, et al. Semen quality in papaya workers with long term exposure to ethylene dibromide. Br J Ind Med 1987; 44: 317-26.

30 Ratcliffe JM, Schrader SM, Clapp DE, Halperin WE, Turner TW, et al. Semen quality in workers exposed to 2-ethoxyethanol. Br J Ind Med 1989; 46: 399-406.

31 Tielemans E, Burdorf A, te Velde ER, Weber RF, van Kooij $\mathrm{RJ}$, et al. Occupationally related exposures and reduced semen quality: a case-control study. Fertil Steril 1999; 71: 690-6.

32 Mortensen JT. Risk for reduced sperm quality among metal workers, with special reference to welders. Scand J Work Environ Health 1988; 14: 27-30.

33 Bonde JP, Hansen KS, Levine RJ. Fertility among Danish male welders. Scand J Work Environ Health 1990; 16: 315-22.

34 Bonde JP. Semen quality and sex hormones among mild steel and stainless steel welders: a cross sectional study. Br J Ind Med 1990; 47: 508-14.

35 Viskum S, Rabjerg L, Jorgensen PJ, Grandjean P. Improvement in semen quality associated with decreasing occupational lead exposure. Am J Ind Med 1999; 35: 257-63.

36 Abell A, Ernst E, Bonde JP. Semen quality and sexual hormones in greenhouse workers. Scand J Work Environ Health 2000; 26: 492-500.

37 Wyrobek AJ, Watchmaker G, Gordon L, Wong K, Moore D 2nd, et al. Sperm shape abnormalities in carbaryl-exposed employees. Environ Health Perspect 1981; 40: 255-65.

38 Vanhoorne M, Comhaire F, De Bacquer D. Epidemiological study of the effects of carbon disulfide on male sexuality and reproduction. Arch Environ Health 1994; 49: 273-8.

39 Kolstad HA, Bonde JP, Spano M, Giwercman A, Zschiesche W, et al. Change in semen quality and sperm chromatin structure following occupational styrene exposure. ASCLEPIOS. Int Arch Occup Environ Health 1999; 72: 135-41.

40 Rowley MJ, Leach DR, Warner GA, HEller CG. Effect of graded doses of ionizing radiation on the human testis. Radiat Res 1974; 59: 665-78.

41 Bonde JP, Joffe M, Apostoli P, Dale A, Kiss P, et al. Sperm count and chromatin structure in men exposed to inorganic lead: lowest adverse effect levels. Occup Environ Med 2002; 59: 234-42.

42 Shiau CY, Wang JD, Chen PC. Decreased fecundity among male lead workers. Occup Environ Med 2004; 61: 915-23.

43 de Jager C, Farias P, Barraza-Villarreal A, Avila MH, Ayotte $\mathrm{P}$, et al. Reduced seminal parameters associated with environmental DDT exposure and p,p'-DDE concentrations in men in Chiapas, Mexico: a cross-sectional study. J Androl
2006; 27: 16-27.

44 Aneck-Hahn NH, Schulenburg GW, Bornman MS, Farias $\mathrm{P}$, de Jager C. Impaired semen quality associated with environmental DDT exposure in young men living in a malaria area in the Limpopo Province, South Africa. J Androl 2007; 28: 423-34.

45 Toft G, Rignell-Hydbom A, Tyrkiel E, Shvets M, Giwercman A, et al. Semen quality and exposure to persistent organochlorine pollutants. Epidemiology 2006; 17: 450-8.

46 Axmon A, Thulstrup AM, Rignell-Hydbom A, Pedersen HS, Zvyezday V, et al. Time to pregnancy as a function of male and female serum concentrations of $2,2^{\prime} 4,44^{\prime} 5,5^{\prime}-$ hexachlorobiphenyl (CB-153) and 1,1-dichloro-2,2-bis (p-chlorophenyl)-ethylene (p,p'-DDE). Hum Reprod 2006; 21: 657-65.

47 Spano M, Toft G, Hagmar L, Eleuteri P, Rescia M, et al. Exposure to $\mathrm{PCB}$ and p, p'-DDE in European and Inuit populations: impact on human sperm chromatin integrity. Hum Reprod 2005; 20: 3488-99.

48 Skakkebaek NE. Testicular dysgenesis syndrome. Horm Res 2003; 60 (Suppl 3): 49.

49 Storgaard L, Bonde JP, Ernst E, Spano M, Andersen CY, et al. Does smoking during pregnancy affect sons' sperm counts? Epidemiology 2003; 14: 278-86.

50 Ramlau-Hansen CH, Thulstrup AM, Storgaard L, Toft G, Olsen $\mathrm{J}$, et al. Is prenatal exposure to tobacco smoking a cause of poor semen quality? A follow-up study. Am J Epidemiol 2007; 165: 1372-9.

51 Jensen MS, Mabeck LM, Toft G, Thulstrup AM, Bonde JP. Lower sperm counts following prenatal tobacco exposure. Hum Reprod 2005; 20: 2559-66.

52 Jensen TK, Henriksen TB, Hjollund NH, Scheike T, Kolstad $\mathrm{H}$, et al. Adult and prenatal exposures to tobacco smoke as risk indicators of fertility among 430 Danish couples. Am J Epidemiol 1998; 148: 992-7.

53 Jensen TK, Jorgensen N, Punab M, Haugen TB, Suominen J, et al. Association of in utero exposure to maternal smoking with reduced semen quality and testis size in adulthood: a cross-sectional study of 1,770 young men from the general population in five European countries. Am J Epidemiol 2004; 159: 49-58.

54 Jensen MS, Toft G, Thulstrup AM, Henriksen TB, Olsen $\mathrm{J}$, et al. Cryptorchidism concordance in monozygotic and dizygotic twin brothers, full brothers, and half-brothers. Fertil Steril 2008. [Epub ahead of print]

55 Cordier S. Evidence for a role of paternal exposures in developmental toxicity. Basic Clin Pharmacol Toxicol 2008; 102: 176-81.

56 Scialli AR. Paternally mediated effects and political correctness. Reprod Toxicol 1993; 7: 189-90.

57 Anderson D. Overview of male-mediated developmental toxicity. Adv Exp Med Biol 2003; 518:11-24.

58 Marchetti F, Lowe X, Bishop J, Wyrobek AJ. Absence of selection against aneuploid mouse sperm at fertilization. Biol Reprod 1999; 61: 948-54.

59 Trasler JM, Hales BF, Robaire B. Paternal cyclophosphamide treatment of rats causes fetal loss and malformations without affecting male fertility. Nature 1985; 316: 144-6. 